\title{
VALUE-ADDED MODEL OF BASIC MATHEMATICS-PHYSICS TRAINING IN ENGINEERING STUDENTS.
}

\section{MODELO DE VALOR AGREGADO EN LA FORMACIÓN MATEMÁTICA-F́́SICA BÁSICA EN ESTUDIANTES DE INGENIEŔA.}

\author{
Henry de Jesús Gallardo Pérez ${ }^{1}$ \\ Mawency Vergel Ortega ${ }^{2}$ \\ Marling Carolina Cordero Díaz ${ }^{3}$ \\ Universidad Francisco de Paula Santander, \\ San José de Cúcuta, Colombia
}

\begin{abstract}
The added value in education refers to the contribution that the educational institution effectively makes to student learning, expressed as the growth in knowledge, skills and abilities, in a period of time, as a result of their educational

\footnotetext{
Departamento de Matemáticas y estadística, Universidad Francisco de Paula Santander. Doctor en Educación ORCID iD: https://orcid.org/0000-0003-43773903henrygallardo@ufps.edu.co Grupo de investigación Arquimedes

2

Departamento de Matemáticas y estadística, Doctora en Educación, Universidad Francisco de Paula Santander, Colombia. Orcid: https://orcid.org/0000-00018285-2968 Correo electrónico: mawency@ufps.edu.co Grupo de investigación Euler- Quetelet

Departamento de Ciencias contables y financieras. Universidad Francisco de Paula Santander, Colombia. Orcid: https://orcid.org/0000-0002-2913-5588 Correo electrónico: marlingcarolinacd@ufps.edu.co
}

experience. The objective of the research is to determine the added value of the academic work of the Universidad Francisco de Paula Santander in the development of physicalmathematical thinking in engineering students and the estimation of a mathematical model that allows its valuation. In model allows analyzing the trajectory of the group of engineering students who entered in the first semester of 2018 and involves endogenous and exogenous variables associated with the process. The research is framed in the quantitative paradigm, descriptive, multivariate and correlational. We work with two types of data, the secondary data are constituted by the students' grades in 2018 and 2019, this information may present biases because they are different courses with different teachers, however, it allows to see the evolution of students in calculus, statistics and physics 
courses. Primary data were obtained from a test applied in 2018 and a similar test applied in 2019, graded using item response theory. Results were compared and differences were evaluated to estimate the contribution effectively made by the university.

\section{RESUMEN}

El valor agregado en la educación se refiere a la contribución que la institución educativa hace efectivamente al aprendizaje de los estudiantes, expresado como el crecimiento en conocimientos, habilidades y destrezas, en un período de tiempo, como resultado de su experiencia educativa. El objetivo de la investigación es determinar el valor agregado del trabajo académico de la Universidad Francisco de Paula Santander en el desarrollo del pensamiento físico-matemático en los estudiantes de ingeniería y la estimación de un modelo matemático que permita su valoración. En modelo permite analizar la trayectoria del grupo de estudiantes de ingeniería que ingresaron en el primer semestre de 2018 e involucra variables endógenas y exógenas asociadas al proceso. La investigación se enmarca en el paradigma cuantitativo, descriptivo, multivariado y correlacional. Se trabaja con dos tipos de datos, los datos secundarios están constituidos por las calificaciones de los estudiantes en 2018 y 2019, esta información puede presentar sesgos por ser cursos diferentes con profesores diferentes, sin embargo, permite ver la evolución de los estudiantes en los cursos de cálculo, estadística y física. Se obtuvieron datos primarios de una prueba aplicada en 2018 y otra similar aplicada en 2019, calificada mediante la teoría de respuesta al ítem. Se compararon los resultados y se evaluaron las diferencias para estimar la contribución efectivamente realizada por la universidad.

\section{INTRODUCTION}

Physical-mathematical thinking is based on the development and existence of the five types of mathematical thinking and refers to the development of skills that allow comparing, describing, analyzing, synthesizing, abstracting and modeling physical phenomena; is itself the representation of the relationship between physics and mathematics, which places mathematics as the language or tool that allows the characterization of different physical phenomena through the use of algorithms that characterize the language of mathematics as a strategy that allows the construction, interpretation, abstraction and consolidation of meanings for the teacher and the student [1]. Thus, the development of physical-mathematical thinking involves the student being able to mathematize the different physical phenomena and implies that both the different types of mathematical thinking and physical thinking are being developed simultaneously [2,3].

Now, value added refers to the contribution that educational institutions effectively make to student learning [4], both at the construct and methodological level [5] and to student achievement, expressed as the growth in knowledge, skills, abilities and other attributes that students have gained, over a period of time, as a result of their experiences within the institution [6]. Thus, it can be defined as the magnitude of the effect of the educational institution on the educational outcomes of its students, which go beyond their grades and affect their future opportunities [7].

The research aims to determine the added value of the academic work of the Universidad Francisco de Paula Santander in the development of physical-mathematical thinking in engineering students and the estimation of a mathematical model that allows its assessment in order to find the effect of the basic cycle of mathematics and physics in students of engineering programs at 
the university, understood as those activities, processes and teaching and learning strategies [8-10] provided by the institution to contribute to the development of physical-mathematical thinking of students.

\section{MATERIALS AND METHODS}

The research is framed in the quantitative paradigm, cross-sectional, explanatory and correlational. The population under study is constituted by the engineering students of the Universidad Francisco de Paula Santander who entered in the first academic semester of 2018, with the following inclusion criteria who took the mathematics and physics courses always in their academic program, that is, those students who took equivalencies or who homologated subjects are excluded

We work with two types of data to evaluate the contribution that UFPS effectively provides to the selected students. The primary data correspond to test applied in 2018 and similar test applied in 2019; each test was designed and scored using item response theory [11-14]; the results allow comparisons to be made and differences to be assessed. Secondary data are constituted by the grades obtained by students in their mathematics and physics subjects of the basic cycle during 2018 and 2019, this information may be biased because they are different courses with different teachers, however, it allows establishing the evolution of students in calculus, statistics and physics. An additional criterion is adopted for students who have lost a subject, in this case only the grade obtained in the course they pass is included.

The faculty of engineering of the Universidad Francisco de Paula Santander offers seven undergraduate programs: civil engineering (P1), systems engineering (P2), electronic engineering (P3), electromechanical engineering (P4), industrial engineering (P5), mining engineering
(P6) and mechanical engineering (P7). Each program has a different curricular design in which each subject is assigned a name and is located in a specific semester; however, for the present work, similar subjects have been grouped together regardless of the semester in which they are taken, as long as they are in the first four semesters of the basic training cycle: differential calculus (C01), integral calculus (C02), vector calculus (C03), differential equations (C04), linear algebra (C05), numerical analysis (C06), statistics and probability (C07), mechanical physics (C08), electromagnetic physics (C09) and waves and particles (C10).

Multivariate data analysis [15-17] is applied to the information collected, disaggregating information by academic program and taking the results to estimate a multivariate regression model to establish the added value of the university in the academic training of its students, expressed as the difference between the student's actual and expected performance. This type of valueadded models allow measuring the educational progress of students over time, since there are several measurements of the same individual over time.

\section{RESULTS}

Two tests were developed to evaluate the development of thinking and competencies in mathematics and physics of students entering the seven academic engineering programs. The tests are performed with the item response theory methodology, which allows evaluating, for each item, the possibility of guessing, difficulty and discrimination capacity. The value of the test is the accumulated value of all items. Figure 1 shows the characteristic curves corresponding to the Rash model [18] for the two tests. It can be seen that both have a similar degree of difficulty and discrimination ability, with a slight difference in the probability of guessing. 


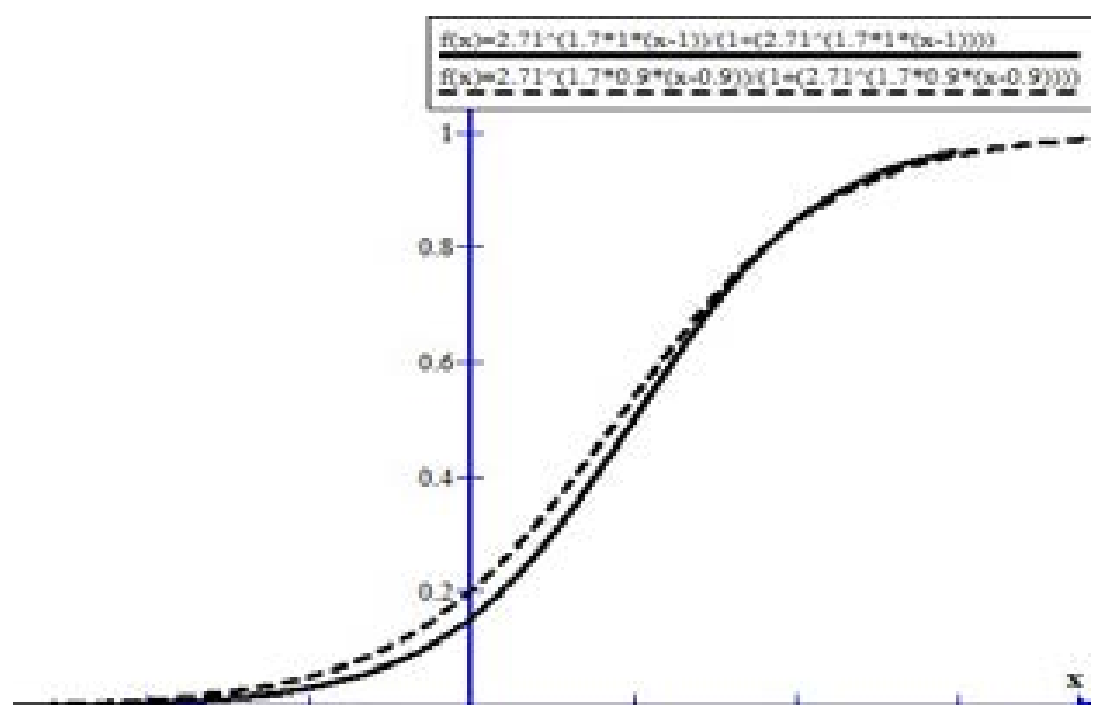

Figure 1. Characteristic curve for pretest and posttest

Figure 2 compares the results of the two tests. In general, it can be seen that the curve corresponding to the post-test is shifted to the right, indicating slightly better results than those obtained in the pre-test; it can also be seen that $\begin{array}{llll}5 & 3 & 1\end{array}$ the standard deviation is slightly lower in the post-test than in the pre-test results.

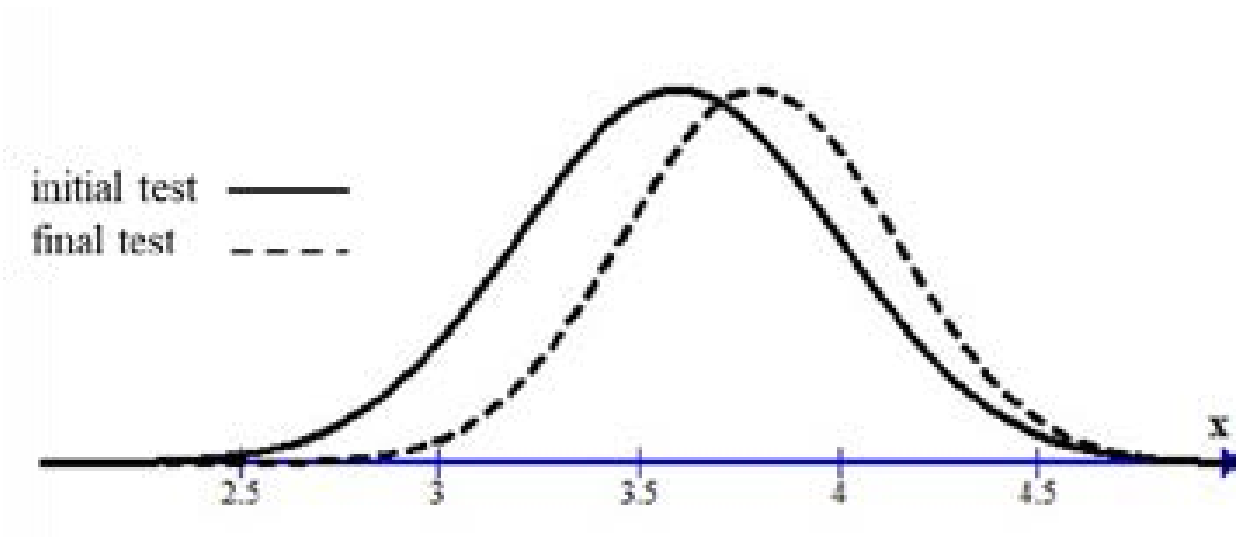

Figure 2. Distribution of pretest and posttest results.

Now, adjusting the scores on a scale of zero to five, in the pretest an average score of 3.64 with a standard deviation of 0.429 was obtained, while in the posttest the average was 3.81 with a standard deviation of 0.343 . The results were compared by means of a paired differences test, which yielded a $t=-6.414$ value with a unilateral significance close to zero, from which it can be concluded that the difference between the results of the posttest with reference to those of the pretest is significant. 
Figure 3 shows the results obtained considering only the mathematics courses; in this case, the difference between the results of the two tests is smaller than when they are considered in general. In mathematics, the average in the pretest was 3.71 with a standard deviation of
0.45 while in the posttest the average was 3.82 with a standard deviation of 0.40 . The paired differences test yielded a t-value of 3.784 with one-sided significance close to zero, so it can be concluded that there is a significant difference between the two results.

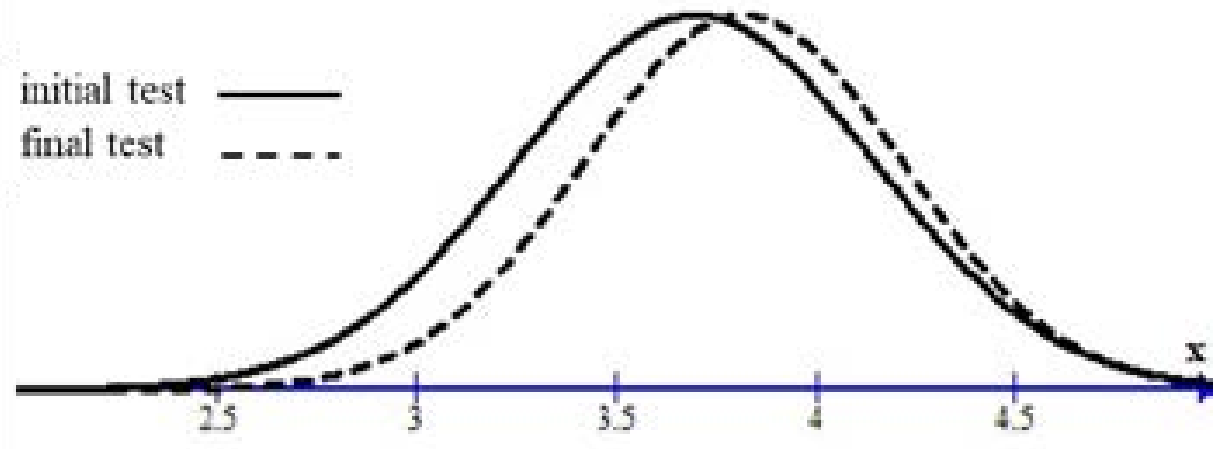

Figure 3. Distribution of pretest and posttest mathematics results.

Figure 4 compares the results obtained considering only the physics courses; in this case, the difference between the results of the two tests is greater than for the two previous cases. In physics, the average in the pretest was 3.38 with a standard deviation of 0.55 while in the posttest the average was 3.92 with a standard deviation of 0.44 . The paired differences test yielded a t-value $=-9.036$ with one-sided significance close to zero, so it can be concluded that there is a significant difference between the two results, but there is a greater difference in the physics results than in mathematics or in the overall consolidation.

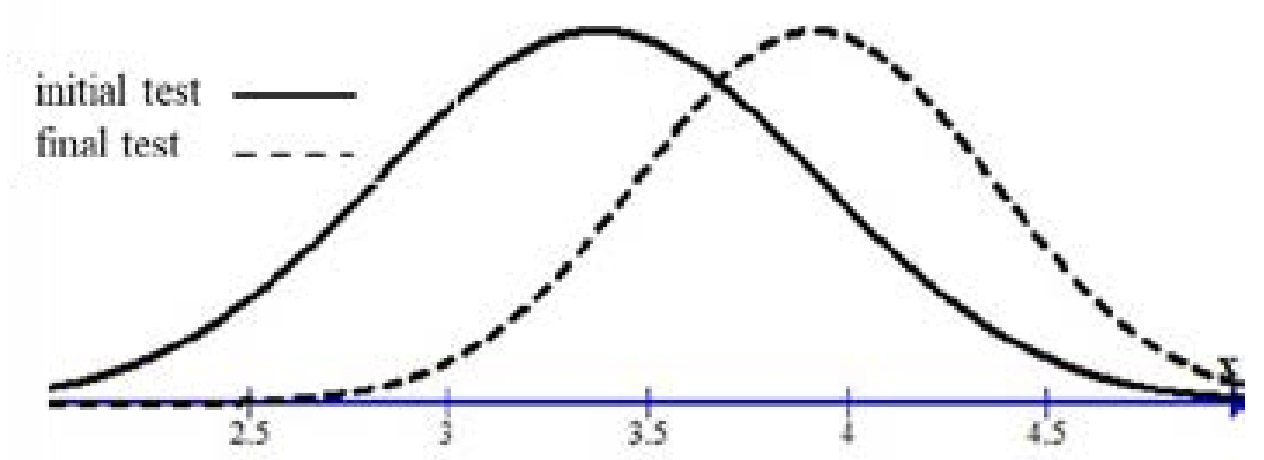

Figure 4. Distribution of results in pretest and posttest physics. 
Figure 5 shows the error bar chart, which shows the average value obtained together with the $95 \%$ confidence interval for its estimation, allowing comparison of pretest and posttest results by academic program. A significant increase in the average can be seen in all programs, with more accentuated differences in civil engineering and electronic engineering.

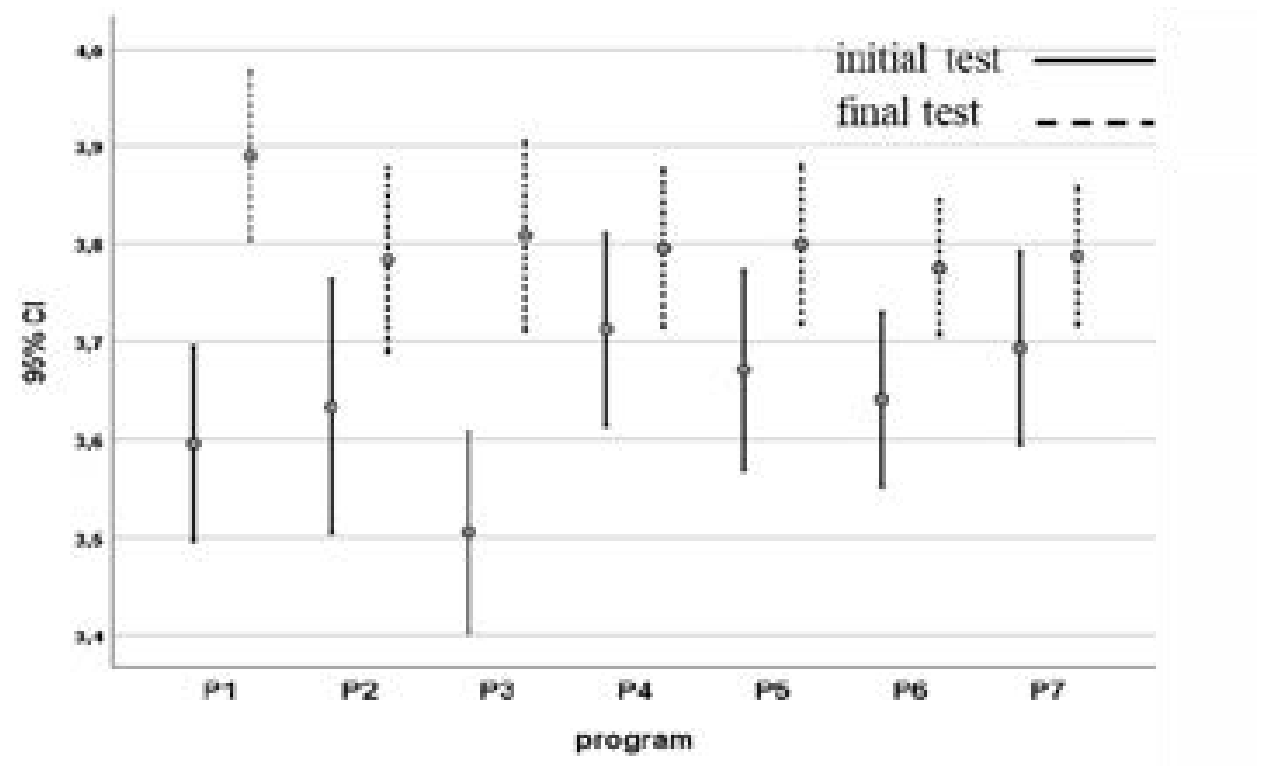

Figure 5. Pretest and posttest results by academic program

Figure 6 shows the students' results in the ten courses that make up their basic cycle in mathematics and physics. The grade is assigned on a scale of zero to five with a passing grade of three. For each course, the average grade is presented with an interval of two standard deviations. The greatest dispersion is found in the first semester courses differential calculus and mechanical physics; however, there is no growth in the average grades as the student advances in his studies. Improvement is only seen in physics courses.

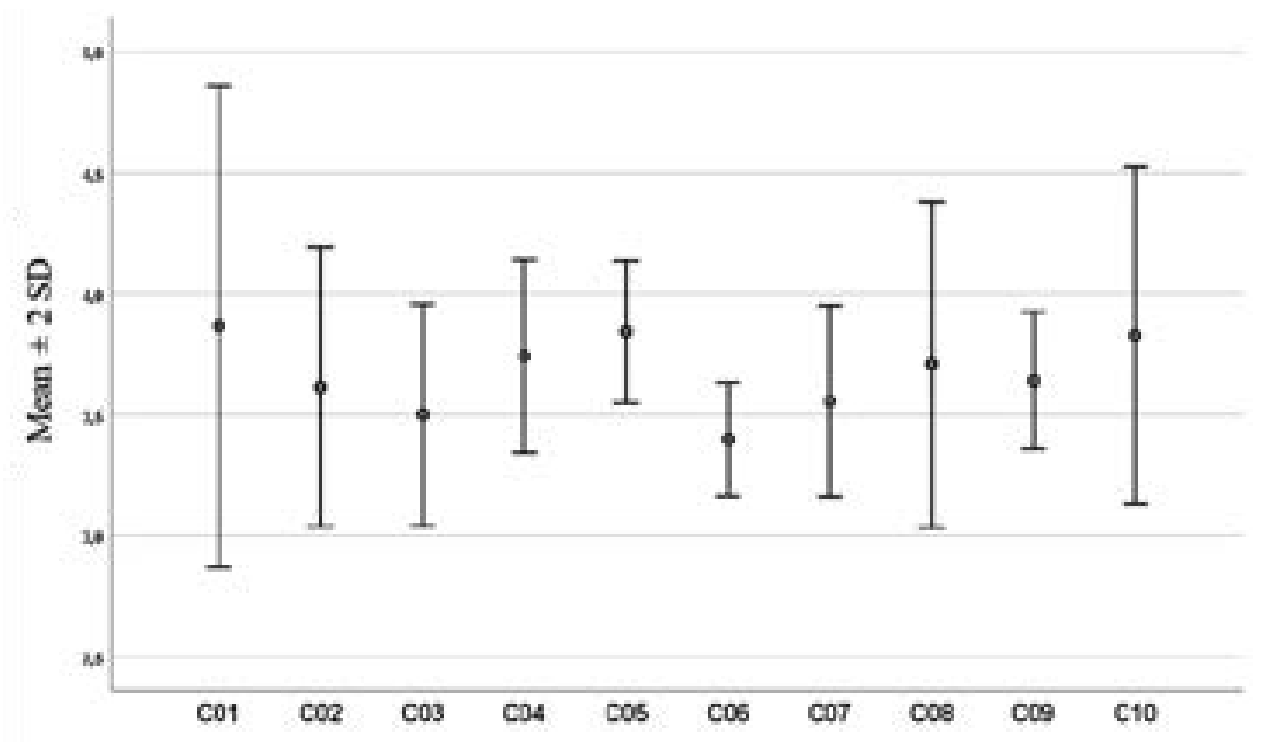

Figure 6. Grades in basic mathematics and physics courses 
The added value of the basic cycle training of the engineering student by the university is defined as the difference between the values obtained in the posttest and pretest; for the model, this difference will be estimated according to the academic results of the students in the ten courses that comprise it. A linear regression model (equation 1) is adjusted, which fits with a Fisher's test value of 4.73 and bilateral significance of 0.030 .

$$
\begin{gathered}
V A=-0,754+0,022 \mathrm{C} 01+0,027 \mathrm{C} 02+0,036 \mathrm{C} 03+0,175 \mathrm{C} 04+0,147 \mathrm{CO} 05+0,191 \mathrm{C} 06+0,079 \mathrm{CO} 07+ \\
0,160 \mathrm{C} 08+0,007 \mathrm{C} 09+0,009 \mathrm{C} 10
\end{gathered}
$$

The average value of the value added is estimated at 0.16 with a standard deviation of 0.35. The paired difference comparison test yields a t-value $=6.4$ with $p$-value $<0.001$. On the other hand, when performing a one-factor analysis of variance to compare the value added by academic program, $\mathrm{F}=1.84$ with $p$-value $=0.89$ was found. Table 1 shows the average value added and its standard deviation by academic program.

Table 1. Value added by academic program

\begin{tabular}{llllllll}
\hline & P1 & P2 & P3 & P4 & P5 & P6 & P7 \\
\hline Arithmetic Mean & 0,29 & 0,15 & 0,30 & 0,08 & 0,13 & 0,13 & 0,09 \\
Standard deviation & 0,30 & 0,43 & 0,36 & 0,35 & 0,36 & 0,36 & 0,38 \\
\hline
\end{tabular}

\section{DISCUSSION}

The value-added model estimated for the basic training of students in the university's engineering courses identifies a greater contribution in its estimation by the academic results of students in the courses of differential equations, linear algebra and mechanical physics. The results obtained here allow differentiating the contribution by academic program, finding greater differences in civil engineering and electronic engineering, followed by mining engineering, industrial engineering and systems engineering.

It is to be expected that there is variability in the academic results of the students in the different training courses. In this case, greater variability was found in the courses of the first semesters; however, a higher arithmetic average was also found in these courses, which would provide a basis for the inclusion of new explanatory variables in the process.
A statistically significant difference is found, using paired difference test, between the score obtained in the posttest with respect to the pretest, which indicates a significant increase in the development of mathematical physical thinking in engineering students at the university; that is, it reflects that the academic training provided by the institution in the basic cycle of mathematics and physics for engineering students contributes significantly both in the development of competencies and in the development of mathematical physical thinking of the students.

When establishing comparisons between the results of the initial and final tests, disaggregating by competencies in mathematics and physics, it is found that students have a lower average in the test for assessment of physical thinking than mathematical: however, the final test allows to establish that the average score for physics increased significantly with respect to mathematics, thus, it can be inferred that the added value of basic training in engineering 
students at the Francisco de Paula Santander University is significantly higher and develops more physical thinking than mathematical thinking.

\section{CONCLUSIONS}

The tests designed to assess the development of competencies in basic fundamentals of engineering students met the statistical and conceptual requirements defined by the methodology used in the item response theory, which is significant when assessing the added value of academic training.

A model for estimating the added value of basic training in mathematics and physics for university engineering students is adjusted according to the academic results in the courses of this cycle, which is basic for the construction of new models including other explanatory variables and, if possible, the inclusion of non-numerical qualitative variables, which will be the subject of another research.

The benefits of the model are that it allows us to explore the pedagogical practices of teachers in those programs with the greatest impact on the added value of academic training and to establish strategies to increase student learning.

Engineering students develop mathematical physical thinking in the basic cycle of their training, then it is established that there is significant added value in basic training for university engineering students

\section{BIBLIOGRAPHIC REFERENCES}

[1] Gallardo H, Villamizar D and Maldonado E 2020 Project based pedagogy in the development of physical-mathematical thinking Journal of Physics: Conference Series 1674012013

[2] Moreira M 2014 Enseñanza de la física: aprendizaje significativo, aprendizaje mecánico y criticidad Revista de Enseñanza de la Física 26(1) 45-52

[3] Castiblanco O and Viscaíno D 2009 La didáctica de la física desde la formación de imágenes en el pensamiento Journal of Science Education 1075

[4] Franco-Gallego J 2019 Educación superior en Colombia: relación entre valor agregado estudiantil y remuneraciones Educación y Educadores 22(1) 25-50

[5] Navarro E 2013 El valor añadido en educación: cuestiones teóricas y metodológicas (Madrid: Universidad Complutense de Madrid)

[6] OECD 2011 Measuring improvements in learning outcomes: Best practices to assess the value-added of schools (New York: OECD Publishing)

[7] Saunders L 1998 Value Added measurement of school effectiveness: An overview (Washington: National Foundation of Economic Research)

[8] Mcfrey D, Lockwood J, Koretz D, Louis T and Hamilton L 2004 Models for ValueAdded Modeling of Teacher Effects Journal of Education and Behavior Statistics 29(1) 67-101

[9] Meyer R 1997 Value-Added Indicators of School Performance: A Primer Economics of Education Review 16(3) 283-301 
[10] Raudenbush S 2004 What Are ValueAdded Models Estimating and What Does This Imply for Statistical Practice? Journal of Educational and Behavioral Statistics 29(1) 121-129

[11] Abal F, Lozzia G, Aguerri M, Galibert M and Attorresi H 2010 La escasa aplicación de la teoría de respuesta al ítem en test de ejecución típica Revista Colombiana de Psicología (19)1 111-122

[12] Attorresi H, Lozzia G, Abal F, Gilbert M and Aguerri M 2009 Teoría de respuesta al ítem. Conceptos básicos y aplicaciones para la medición de constructos psicológicos Revista Argentina de Clínica Psicológica 18(2) 179-188

[13] Prieto G and Delgado A 2003 Análisis de un test mediante el modelo de Rash Psicothema 25(1) 94-100

[14] Muñiz J 2010 Las teorías de los tests: teoría clásica y teoría de respuesta a los ítems Papeles del psicólogo 31(1) 57-66

[15] Goldstein H 1999 Multilevel statistical models (Londres: Institute of Education. Multilevel Models Project)

[16] Quené H \& Van Den Bergh H 2004 On multi-level modeling of data from repeated measured designs: a tutorial Speech Communication 43 103-121

[17] Bologna E 2012 Tendencias en el análisis estadístico Revista Evaluar 11 59-84

[18] Cortada de Kohan N 2004 Teoría de respuesta al ítem Revista Evaluar 4 95110 